\title{
HUBUNGAN CARA PEMBERIAN AIR SUSU IBU (ASI) TERHADAP KEJADIAN DIARE PADA BAYI 6-11 BULAN DI PUSKESMAS KOTA CIMAHI PROVINSI JAWA BARAT
}

\author{
${ }^{1}$ Yeni Suryamah, Kantor Kesehatan Pelabuhan Kelas II Bandung \\ yeni_suryamah@hotmail.com
}

\begin{abstract}
Diarrhea disease is still a public health problem in developing countries such as Indonesia because of morbidity and mortality which is still high. On Cimahi City in 2013 the incidence of diarrhea was on third place (10.69\%) after acute respiratory infection and acute nasopharyngitis on patients age group 0 to less than one year. Number of less-one-year infants with diarrhea disease who came to the public health center in Cimahi City was $19.53 \%$ and the number of 1-4 years old toddlers was $13.41 \%$ in 2014.. Many factors play an important role against children under five's illness especially diarrhea which among its are breastfeeding (breast milk). Some ways of breastfeeding are by giving directly to the baby or give it indirectly through expressed breast milk. The purpose of this study was to determine the relationship between the way of breastfeeding and the incidence of diarrhea in infants 6-11 months in public health centers Cimahi City in 2015 before and after controlling for variables maternal education, maternal occupation, socio economic status, hygiene of food and drink, sex, age infant, complementary feeding, and nutritional status. The study design using case-control study in which cases were infants aged 6-11 months who come to the public health center and was diagnosed as a case of diarrhea while control is taken at the same public health center and in the same week and do not suffer from diarrhea or infants who visit for immunizations. Case control comparative is $1: 1$ with 154 chosen samples from each group. Multivariate analysis using logistic regression. The survey results revealed significant correlation between expressed breast milk with the incidence of diarrhea in infants $(p=0.019)$. The expressed breast milk has a protective effect 0.546 times less protection against diarrhea compared with infants fed breast milk directly. While the not breast milk / formula milk is known that there are no significant relationship with the occurrence of diarrhea $(p=0.858)$. There was no significant relationship between how breastfeeding by the incidence of diarrhea in infants after the controlled variable hygiene of food and drinks with $p$ value of $0.055(95 \%$ CI 0.3601.011) and 0.875 (95\% CI 0.360-1.011). It is hoped that the department of health and public health centers can increase promotional efforts to expectant mothers and mothers of infants, especially on hygiene of food and drink for use by infants including handwashing, increased promotional efforts health on complementary feeding, and the need for socialization of giving expressed breast milk to the baby to support the movement of breastfeeding until the age of two years.
\end{abstract}

Keywords:

How to breastfeeding; infant diarrhe; case-control study

\section{PENDAHULUAN}

Diare masih menjadi penyebab utama kematian balita di Indonesia dan proporsi terbesar penderita diare pada balita terdapat pada kelompok umur 6-11 bulan yaitu 21,65\%. Sementara berdasarkan data laporan rumah sakit, penyakit diare dan gastroenteritis merupakan penyakit urutan pertama yang Jurnal Penelitian Kesehatan STIKes Dharma Husada Bandung menyebabkan pasien rawat inap di rumah sakit $(8,23 \%)$ (Kemenkes, 2011).

Di Kota Cimahi tahun 2013 kejadian diare merupakan peringkat ketiga $(10,69 \%)$ setelah ISPA dan Nasofaringitis akut pada penderita rawat jalan golongan umur $0-<1$ tahun. Sementara pada golongan umur 1-4 tahun 
sebesar $(9.81 \%)$. Penderita diare yang dirawat inap di RS Kota Cimahi tahun 2013 usia 29 hari - 1 tahun merupakan proporsi terbanyak yaitu $21,74 \%$. Sementara umur 1-4 tahun sebesar 7,56\% (Profil Kesehatan Kota Cimahi, 2013). Jumlah penderita diare bayi usia kurang satu tahun pada tahun 2014 yang datang ke puskesmas di Kota Cimahi sebesar 19,53\%. dan balita 1-4 tahun sebesar 13,41\%. Pada tahun 2014 terdapat satu kasus kematian balita yang disebabkan diare. (Laporan Program Diare Dinas Kesehatan Kota Cimahi tahun 2014)

Banyak faktor yang berperan penting terhadap kesakitan balita terutama kejadian diare diantaranya adalah pemberian Air Susu Ibu (ASI). Cakupan ASI Eksklusif di Kota Cimahi tahun 2013 sebesar 59,6\% masih dibawah target Standar Pelayanan Minimal yaitu $75 \%$ (Profil Kesehatan Kota Cimahi, 2013). Sementara pada tahun 2014 cakupan ASI Eksklusif sebesar 63,39\% (Laporan KIA Gizi Dinkes Kota Cimahi, 2014).

Alasan yang menjadi penyebab kegagalan praktik ASI eksklusif bermacam-macam seperti budaya memberikan makanan pralaktal, memberikan tambahan susu formula karena ASI tidak keluar, menghentikan pemberian ASI karena bayi atau ibu sakit, ibu harus bekerja, dan ibu ingin mencoba susu formula. (Kemenkes 2010).

WHO mengklasifikasikan pemberian makanan susu pada bayi berdasarkan empat kategori yaitu : (Lamberti, 2011).

1. Ekslusif (ASI dari ibunya atau dari ibu lain yang menghasilkan ASI atau ASI Perah),
2. Predominan (ASI dari ibunya atau dari ibu lain yang menghasilkan ASI atau ASI Perah, mendapatkan air minum, tidak mendapatkan makanan lain yang berbahan cairan kecuali jus buah buahan dan air gula, mendapatkan vitamin drops atau sirup, suplemen mineral yang diresepkan dokter),

3. Parsial ASI (ASI dari ibunya atau dari ibu lain yang menghasilkan ASI atau ASI perah, mendapatkan makanan cair lain atau yang bukan cair termasuk susu dan produk bukan susu)

4. Tidak pernah ASI (mendapatkan susu formula atau susu binatang, tidak mendapatkan ASI)

Penelitian Rollins (2013) menyatakan bahwa risiko setelah di adjusted pada bayi tidak pernah diberikan ASI (diberikan susu formula atau susu binatang) 1,29 lebih besar terhadap kejadian diare akut dibandingkan dengan bayi yang diberikan ASI parsial $(1,22)$. Sementara pada penelitian Ehlayel (2009) risiko diare pada bayi cukup tinggi dan secara statistik signifikan pada ASI parsial $(48,7 \%$ dengan 32.5\%) dan tidak pernah ASI $(37,3 \%$ dengan $32.5 \%, \mathrm{p}<0,001)$. Hasil multivariate menunjukan pemberian susu formula berisiko 2,68 kali sementara ASI parsial sebesar 1,60 kali.

Beberapa tahun terakhir gerakan gencar menyusui ASI eksklusif telah dilakukan oleh Kementrian Kesehatan hingga ke tingkat puskesmas, selain itu Lembaga Swadaya Masyarakat (LSM) turut berperan aktif dalam gerakan ASI eksklusif. Hal ini mendorong ibu bayi untuk memberikan ASI nya 
bagaimanapun caranya agar dapat mencapai status ASI eksklusif. Beberapa cara pemberian ASI antara lain dengan cara memberikan langsung kepada bayinya dan memberikan secara tidak langsung melalui ASI Perah (ASIP).

Praktik memerah ASI meningkat seiring dengan ketersediaan peralatan makan bayi komersial. Memerah ASI menjadi terbiasa dan kesempatan memperkenalkan cara lain memberi makan bayi. Di beberapa keluarga ada yang berpendapat bahwa menyusui merupakan pengurangan tugas, sangat mungkin lebih dari itu, seseorang yang bisa melakukannya dan berpotensi untuk menciptakan hubungan khusus antara ibu dan bayinya (Johns, 013).

Hasil systematic review Johns (2013) mencantumkan beberapa penelitian sebelumnya menyatakan sebesar $0,06 \%$ bayi yang mendapatkan ASI perah secara ekslusif (Shealy et al,2008). Sebesar 98\% ASI pernah diperah, dan menyusui langsung mengalami penurunan dari 34\% tahun 2000-2001 menjadi 27\% tahun 2006-2008 (Hornbeak et al, 2010). Pemberian susu formula dari $31 \%$ menjadi $18 \%$ (Hornbeak, 2010).

Pemberian ASIP dilakukan selama bayi tidak bersama ibunya dengan menggunakan botol, cup feeder atau gelas serta sendok. Karena pemberiannya melalui media lain, maka kebersihan peralatan ini juga harus dijaga. Karena bukan tidak mungkin jika peralatan untuk memberikan ASIP ini tidak bersih, bisa tercemar bakteri atau lainnya (Nenglita, 2011).
Penanganan tambahan yang terkait dengan memerah, penyimpanan, dan pemberian susu botol berikutnya dari ASI perah menghasilkan risiko tambahan untuk infeksi pada bayi (Geraghty, 2010 dalam Johns 2013)

ASI, pembekuan dan pemberian ASI yang tidak langsung akan menghilangkan kandungan vitamin, dan seperti susu formula, menjadi berisiko terkontaminasi, hal seperti itu harus mematuhi penanganan saat proses persiapan (Boo 2001 dalam Johns 2013) Pembekuan, pencairan dan pemanasan dan microwave semua memiliki potensi untuk menjamin kualitas dan keamanan ASI (Hurst, 2010; Amir, 2006 dalam Johns 2013)

Usus bayi mungkin akan terpengaruh oleh bakteri lain yang berkembang dan diperkenalkan melalui kontaminasi di proses pengumpulan ASI. Pemberian ASI yang disimpan pada bayi mungkin memiliki konsekuensi yang berbeda pada kesehatan usus bayi dibandingkan dengan menyusui langsung, dan ini harus diselidiki lebih lanjut. (The Academy of Breastfeeding Medicine (ABM) protocol, 2010).

Berdasarkan beberapa cara pemberian ASI tersebut, belum pernah diketahui kekuatan hubungan antara cara pemberian ASI terhadap kejadian diare. Adapu tujuan dari penelitian ini adalah :

1. Mengetahui gambaran kejadian diare pada bayi 6-11 bulan di puskesmas Kota Cimahi tahun 2015 
2. Mengetahui gambaran cara pemberian ASI pada bayi 6-11 bulan di puskesmas Kota Cimahi tahun 2015

3. Mengetahui hubungan cara pemberian ASI terhadap kejadian diare pada bayi 6-11 bulan di puskesmas Kota Cimahi tahun 2015 sebelum dan setelah dikontrol terhadap variabel pendidikan ibu, pekerjaan ibu, status sosial ekonomi, hygiene makanan dan minuman, jenis kelamin, usia bayi, makanan pendamping ASI, dan status gizi

Diare merupakan suatu kondisi seseorang buang air besar dengan konsistensi tinja lembek atau cair, bahkan dapat berupa air saja dan frekuensinya lebih sering (biasanya tiga kali atau lebih) dalam satu hari (Kemenkes, 2011). Sementara menurut Chin (2009), penyakit diare dilihat dari sudut pandang praktis dapat dibagi menjadi 6 gejala klinik yaitu :

1. Diare ringan, diatasi dengan pemberian larutan rehidrasi oral yang terdiri dari air, glukosa dan elektrolit, sedangkan etiologi spesifik tidaklah penting dalam penatalaksanaan;

2. Diare berdarah (disentri) disebabkan oleh organisme seperti Shigella, E coli 0157:H7 dan beberapa organisme tertentu;

3. Diare persisten yang berlangsung paling sedikit selama 14 hari;

4. Diare berat seperti pada cholera;

5. Diare ringan tanpa dehidrasi karena muntah, disebabkan oleh virus gastroenterides; diare karena toksin, seperti yang disebabkan oleh Staphylococcus aureus, Bacillus cereus, atau CI perfringens; dan

6. Colitis haemoragika, dengan diare cair mengandung darah banyak tetap tanpa demam atau fekal lekositosis.

Menurut WHO (2010) dalam Miftakhuddiniyah (2013) transmisi penyebaran organisme pathogen diare berasal dari tinja seseorang ke mulut orang lain yang dikenal sebagai "faecal-oral transmission". Mungkin ada perbedaan dalam jumlah organisme yang diperlukan untuk menyebabkan penyakit klinis, namun dalam rute patogen mengambil perjalanan antara individu (misalnya dari tinja melalui makanan atau air, yang kemudian tertelan).

Menurut Kementrian Kesehatan (2011) cara penularan diare akut umumnya melalui jalan mulut (fecal oral) yaitu melalui makanan atau minuman yang tercemar kuman atau kontak langsung tangan penderita atau tidak langsung melalui lalat (melalui 5f : faeces, flies, food, fluid, finger)

Menurut Kementrian Kesehatan (2013) kegiatan pencegahan penyakit diare yang benar dan efektif yang dapat dilakukan adalah :

1. Perilaku Sehat, meliputi :

a. Pemberian ASI eksklusif untuk bayi sampai usia 6 bulan. Setelah 6 bulan proses kehidupannya, pemberian ASI harus diteruskan sambil ditambahkan dengan makanan lain (proses menyapih)

b. Pemberian makanan pendamping ASI yang baik meliputi perhatian terhadap kapan, apa dan bagaimana makanan pendamping ASI diberikan, yaitu : 
- Perkenalkan makanan lunak ketika anak berumur 6 bulan dan teruskan pemberian ASI

- Tambahkan macam makanan setelah anak berumur 9 bulan atau lebih dan berikan makanan lebih sering $(4 \mathrm{x}$ sehari)

- Setelah anak berumur 1 tahun berikan semua makanan yang dimasak dengan baik (4-6 x sehari), dan teruskan pemberian ASI bila mungkin.

- Tambahkan minyak, lemak dan gula ke dalam nasi/bubur dan biji-bijian untuk energi.

- Tambahkan hasil olahan susu, telur, daging, ikan, kacang kacangan, buah buahan dan sayuran berwarna hijau ke dalam makanannya.

c. Menggunakan air yang bersih dan melindungi air tersebut dari kontaminasi mulai dari sumbernya sampai penyimpanan di rumah

d. Biasakan mencuci tangan dengan sabun dan air bersih pada 5 titik kritis, yaitu : sebelum makan, sebelum mengolah dan menghidangkan makanan, setelah buang air besar dan kecil, setelah mengganti popok bayi, sebelum menyusui bayi

e. Pengelolaan standar makanan sesuai standar WHO, meliputi : jaga kebersihan, pisahkan bahan makanan matang dan mentah, masak makanan hingga matang, simpan makanan pada suhu aman, gunakan air bersih dan bahan makanan yang baik f. Membuang tinja bayi yang benar, yaitu : kumpulkan segera tinja bayi dan buang di jamban, bantu anak BAB di tempat yang bersih dan mudah dijangkau olehnya, bila tidak ada jamban pilih tempat untuk membuang tinja seperti di dalam lubang atau di kebun kemudian di timbun, bersihkan dengan benar setelah $\mathrm{BAB}$ dan cuci tangan dengan sabun.

g. Pemberian imunisasi campak segera setelah bayi berumur 9 bulan. Anak yang sakit campak sering disertai diare, sehingga pemberian imunisasi campak juga dapat mencegah diare.

2. Penyehatan lingkungan meliputi :

a. Keluarga harus mempunyai jamban yang berfungsi baik dan dapat dipakai oleh seluruh anggota keluarga

b. Penyediaan air bersih yang cukup disetiap rumah tangga

c. Pengelolaan sampah. Tempat sampah harus disediakan, sampah harus dikumpulkan setiap hari dan dibuang ke tempat penampungan sementara. Bila tidak terjangkau oleh pelayanan pembuangan sampah ke tempat pembuangan akhir sampah dapat dilakukan pemusnahan sampah dengan cara ditimbun atau dibakar.

d. Sarana pembuangan air limbah. Air limbah pabrik atau limbah rumah tangga harus dikelola sedemikian rupa agar tidak menjadi sumber penularan penyakit. 


\section{Air Susu Ibu (ASI)}

Pada systematic review Johns (2013) cara pemberian ASI dibagi menjadi : memerah ASI (juga dikenal sebagai pompa) adalah untuk menggambarkan penggunaan pompa untuk mendapatkan ASI, dan memerah ASI menggunakan tangan. Menyusui digunakan untuk menggambarkan tindakan menyusui langsung dari payudara, dan pemberian ASI termasuk cara apapun dimana ASI diberikan kepada bayi.

Cara pemberian ASI kepada bayi yang terdiri dari memberikan ASI secara langsung, memberikan ASI secara tidak langsung melalui ASI Perah (ASIP) dan bukan ASI. Kualitas ASI yang paling baik antara lain : (Annisakarnadi , 2014)

1. ASI ibu yang menyusui bayi secara langsung

2. ASI perah yang masih segar (masih cair dan belum dibekukan)

3. ASI beku

Menyusui berpengaruh terhadap kontak langsung ibu dan bayi. Ikatan kasih sayang ibu dan bayi terjadi karena berbagai rangsangan seperti sentuhan kulit (skin to skin contact). Bayi akan merasa aman dan puas karena bayi merasakan kehangatan tubuh ibu dan mendengar denyut jantung ibu yang sudah dikenal sejak bayi dalam rahim (Miftakhunddiniyah, 2013)

ASI perah diberikan pada saat ibu tidak berdekatan dengan bayinya. Memerah ASI dapat dilakukan dengan tangan bila payudara dalam keadaan lunak. Memerah dengan tangan adalah cara yang paling baik. Cara ini hanya sedikit memerlukan alat sehingga ibu bekerja dapat dengan mudah memerah ASI dimana saja dan kapan saja (Kemenag PP, 2008 dalam Abdullah GI, 2012).

Menurut Johns (2013) ASI yang langsung didapatkan dari payudara sebenarnya cukup langka, setidaknya di negara maju. Beberapa ASI Perah dipersiapkan berdasarkan pertimbangan tak terduga, yang mungkin hanya ibu lakukan sesekali, misalnya ketika ibu perlu untuk pergi keluar tanpa bayinya, saat memperkenalkan makanan sereal pada bayi, bila bayi sakit atau tidak mampu menghisap atau ASI tidak keluar. Selain itu menurut Johnson (2009) dalam Johns (2013) berpendapat bahwa memerah ASI dapat memfasilitasi ibu menjadi mandiri, dan memberikan kebebasan ibu dari tuntutan bayinya.

\section{Faktor Risiko Diare}

Faktor risiko diare yang dimodifikasi Gertsman (2003) terbagi menurut Agent, Host dan Environment, sebagai berikut :

1. Agent

Diare merupakan gejala infeksi yang disebakan oleh bakteri, virus dan parasit perut. Diare dapat terjadi bersamaan dengan penyakit infeksi lainnya seperti malaria dan campak, begitu juga dengan keracunan kimia. Perubahan flora usus yang dipicu antibiotic dapat menyebabkan diare akut karena pertumbuhan berlebihan dan toksin dari Clostridium difficile (Chin J, 2009)

2. Host

Dibagi menjadi dua yaitu factor ibu yang terdiri dari : pendidikan ibu, pekerjaan ibu, 
hygiene makanan minuman dan status ekonomi. Sementara factor bayi terdiri dari : frekuensi buang air besar, usia, jenis kelamin, status gizi, makanan pendamping ASI, ASi (predominan, ASI parsial, susu formula, durasi pendek ASI)

\section{Environment}

Terdiri dari : musim, sumber air (Jenis sarana air bersih, jarak sumber air dengan rumah, jarak sumber air dengan septik tank, menggunakan sumber air kota, menyimpan air dalam wadah tertutup, sumber air dan pencemaran sarana air bersih), saluran pembuangan air limbah, sampah dekat rumah.

\section{METODE PENELITIAN}

Menggunakan desain kasus kontrol. Penelitian ini dimulai dengan mengidentifikasi kasus yaitu penderita diare pada bayi 6-11 bulan. Sedangkan kontrol merupakan bayi 611 bulan yang tidak menderita diare.

Pemilihan desain kasus kontrol digunakan karena desain ini cocok untuk mempelajari multi eksposur yang berhubungan dengan kejadian penyakit (Gertsman, 2003). Dalam hal ini faktor eksposur utamanya yaitu cara pemberian ASI dan beberapa faktor eksposur kovariatnya yang berhubungan dengan kejadian diare yaitu pendidikan ibu, pekerjaan ibu, status social ekonomi, hygiene makanan minuman, jenis kelamin, usia bayi, makanan pendamping ASI dan status gizi. Selain itu peneliti memilih desain kasus kontrol juga dikarenakan adanya keterbatasan dana dan waktu penelitian serta desain ini dinilai efisien dan feasible dikerjakan oleh peneliti.
Penelitian ini dilaksanakan pada bulan Februari sampai dengan Juni 2015, dimulai sejak penyusunan proposal hingga penulisan laporan penelitian. Penelitian berlokasi di seluruh puskesmas di Kota Cimahi yaitu sebanyak 14 puskesmas.

Populasi penelitian ini adalah bayi 6-11 bulan yang berada di wilayah Kota Cimahi pada tahun 2015. Sampel adalah bayi 6-11 bulan yang berada di wilayah Kota Cimahi dan berkunjung ke puskesmas yang ada di Kota Cimahi pada tahun 2015, serta terpilih sebagai sampel dengan memenuhi kriteria inklusi dan ekslusi kasus dan control.

Kasus adalah bayi 6-11 bulan yang berkunjung ke sarana puskesmas di Kota Cimahi pada tahun 2015 dan didiagnosa oleh dokter atau paramedis sebagai kasus diare. Kriteria inklusi kasus yaitu :

1. Penderita bertempat tinggal di Kota Cimahi

2. Subjek adalah ibu bayi 6-11 bulan yang bersedia menjadi responden dalam penelitian ini.

3. penderita hanya dapat disertakan satu kali menjadi kasus selama tahun 2015

Kriteria ekslusi kasus pada penelitian ini yaitu data tidak lengkap pada variabel nama, umur, alamat bayi dan diagnosa

Kontrol adalah bayi 6-11 bulan yang berkunjung ke sarana puskesmas di Kota Cimahi pada tahun 2015 dan didiagnosa oleh dokter atau paramedis bukan kasus diare serta bayi yang berkunjung untuk imunisasi dan penimbangaan berat badan. Tidak menderita diare pada saat yang sama dengan kasus pada 2 
minggu sebelumnya. Kriteria inklusi kontrol yaitu :

1. Bertempat tinggal di wilayah Kota Cimahi

2. Ibu bayi bersedia menjadi responden dalam penelitian ini

3. Tidak terdaftar/tercatat sebagai kasus diare di buku/catatan register puskesmas di Kota Cimahi

4. Kontrol hanya dapat disertakan satu kali sebagai kontrol selama tahun 2015

5. Pengambilan kontrol diambil setelah didapatkan kasus pada minggu yang sama dengan mengambil kontrol yang pertama kali datang ke puskesmas di minggu tersebut.

Kriteria ekslusi kontrol yaitu ibu bayi tidak bersedia menjadi responden dalam penelitian ini, data tidak lengkap pada variabel nama, umur, alamat bayi dan diagnosa. Kontrol terdiagnosa sebagai kasus selama tahun 2015

Besar sampel yang akan diambil dari populasi pada penelitian ini menggunakan rumus pengujian hipotesis perbedaan dua proporsi dari Lemeshow (1997) sebagai berikut:

Besar sampel minimal dihitung 2 (dua) tahap,yaitu :

1. Menghitung besar sampel minimal pada kelompok kategori ASI Perah terhadap kelompok kategori referen ASI langsung/Bukan ASI Perah.

2. Menghitung besar sampel minimal pada kelompok kategori bukan ASI / susu formula terhadap kelompok kategori referen ASI langsung / Bukan ASI Perah
Kemudian dipilih sampel dengan jumlah paling besar dari hasil perhitungan tersebut dimana proporsi $\mathrm{P}_{2}$ dan $\mathrm{OR}$ diperoleh berdasarkan hasil penelitian observasional sebelumnya yang berkaitan dengan kejadian diare bayi sebagai variabel terikat dan cara pemberian ASI sebagai variabel bebas. Perbandingan antara kasus dengan kontrol pada penelitian ini adalah 1:1

Tabel 1. Perhitungan sampel yang terkait dengan hubungan cara pemberian ASI dengan kejadian diare dari penelitian terdahulu

\begin{tabular}{|c|c|c|c|c|c|c|}
\hline Tahap & P2 & OR & P1 & $\boldsymbol{\alpha}$ & $\boldsymbol{\beta}$ & $\boldsymbol{n}$ \\
\hline I & 0,30 & 2 & 0,46 & $5 \%$ & $80 \%$ & 139, \\
(ASI & (Stu & (Leme & 6 & $(1,96$ & $(0,8$ & 79 \\
Perah & di & show, & & ) & $42)$ & \\
terhadap & pen & $1997)$ & & & & \\
ASI & dah & & & & & \\
Langsung) & ulua & & & & & \\
& n di & & & & & \\
& Kot & & & & & \\
& a & & & & & \\
& Ban & & & & & \\
dun & & & & & \\
g) & & & & & \\
II & 0,01 & 9.30 & 0,08 & $5 \%$ & $80 \%$ & 123, \\
(Bukan & (Gir & Strand & & $(1,96$ & $(0,8$ & 13 \\
ASI & ma & $(2012)$ & & ) & $42)$ & \\
terhadap & $(20$ & & & & & \\
ASI & $11)$ & & & & & \\
Langsung) & & & & & & \\
\hline
\end{tabular}

Berdasarkan perhitungan besar sampel minimal tersebut didapatkan jumlah sampel terbanyak adalah 139,79 bayi sehingga jumlah sampel minimal untuk kelompok kasus dan kontrol masing-masing sebanyak 140 bayi 611 bulan, dan dengan penambahan sebanyak $10 \%$ dari masing masing kelompok tersebut maka total sampel minimal sebanyak 308 bayi 6-11 bulan.

Cara pengambilan sampel pada penelitian ini adalah sebagai berikut : 
1. setiap bayi usia 6-11 bulan yang datang ke puskesmas dan mendapatkan pelayanan dilakukan pengecekan di register harian rekam medis untuk mengetahui variabel dependen (kejadian diare).

2. setelah mendapatkan pelayanan puskesmas kemudian dilakukan wawancara untuk mengetahui variabel cara pemberian ASI, pendidikan ibu, pekerjaan ibu, status sosial ekonomi, hygiene makanan dan minuman, jenis kelamin, usia bayi, makanan pendamping ASI dan status gizi.

3. kegiatan tersebut dilakukan sampai jumlah sampel minimal terpenuhi.

4. melakukan kunjungan ulang ke rumah yang terpilih menjadi sampel bila masih dibutuhkan informasi yang terkait dengan variabel penelitian

pemilihan sampel dilakukan sesuai dengan kriteria inklusi dan ekslusi sampai jumlah sampel minimal terpenuhi. Instrumen penelitian menggunakan kuesioner tertutup untuk data primer yaitu untuk mengetahui variabel cara pemberian ASI, pendidikan ibu, pekerjaan ibu, status sosial ekonomi, hygiene makanan dan minuman, jenis kelamin, usia bayi, makanan pendamping ASI dan status gizi. Sementara untuk variabel kejadian diare menggunakan form observasi.

Sebelum dilakukan pengambilan data kuesioner tersebut dilakukan uji reliabilitas pada variabel hygiene makanan minuman untuk mengetahui konsistensi dari seluruh pertanyaan. Uji validitas dan reliabilitas dilakukan di puskesmas Kota Bandung dimana karakteristik bayi dan ibu hampir menyerupai
Kota Cimahi dengan mengambil sebanyak 60 responden

Tenaga pewawancara pada penelitian ini merupakan petugas surveilans puskesmas yang tidak memegang program P2 Diare dan Program KIA-KB. Hal ini berdasarkan pertimbangan kemudahan untuk mendapatkan data dan penelusuran kasusnya. Petugas puskesmas yang libatkan yaitu sebanyak 14 orang dengan tingkat pendidikan minimal lulusan setingkat Diploma satu.

Data dikumpulkan dengan cara wawancara pada subjek penelitian (ibu bayi atau pengasuh bayi) yang dilakukan pada saat ibu bayi atau pengasuh bayi sudah mendapatkan pelayanan di puskesmas. Observasi dilakukan pada buku register puskesmas, register harian diare. Petugas pewawancara yang akan melakukan wawancara, terlebih dahulu dikumpulkan dan diberikan penjelasan berkaitan dengan prosedur pengambilan data.

Pengolahahn data terdiri dari : editing, koding dan data entri. Rancangan Analisis data menggunakan cut off point Receiver Operating Characteristic (ROC), analisis univariate untuk melihat distribusi frekuensi variable yang diteliti, analisis bivariate menggunakan uji chi square dan ukuran asosiasi odds ratio (OR) dan analisis multivariate menggunakan regresi logistik. 


\section{HASIL DAN PEMBAHASAN}

HASIL

Tabel berikut merupakan cara pemberian ASI yang dilakukan oleh ibu bayi.

Tabel 2. Distribusi Cara Pemberian ASI berdasarkan Kasus dan Kontrol di Kota Cimahi

\begin{tabular}{|c|c|c|c|c|c|c|}
\hline \multirow{2}{*}{$\begin{array}{c}\text { Cara } \\
\text { Pemberia } \\
\text { n ASI }\end{array}$} & \multicolumn{2}{|c|}{ Kasus } & \multicolumn{2}{|c|}{ Kontrol } & \multicolumn{2}{|c|}{ Jumlah } \\
\hline & $\mathbf{n}$ & $\%$ & $\mathbf{n}$ & $\%$ & $\mathbf{n}$ & $\%$ \\
\hline $\begin{array}{l}\text { Bukan } \\
\text { ASIP/ASI } \\
\text { langsung }\end{array}$ & 71 & 46.1 & 86 & 55.8 & 157 & 51.0 \\
\hline $\begin{array}{l}\text { ASI } \\
\text { langsung } \\
\text { dan ASIP }\end{array}$ & 20 & 13.0 & 26 & 13.0 & 46 & 15.0 \\
\hline $\begin{array}{l}\text { ASI } \\
\text { langsung } \\
\text { dan susu } \\
\text { formula }\end{array}$ & 25 & 16.2 & 17 & 11.0 & 42 & 13.6 \\
\hline ASIP & 1 & .6 & 1 & .6 & 2 & .6 \\
\hline $\begin{array}{l}\text { ASIP dan } \\
\text { Susu } \\
\text { formula }\end{array}$ & 0 & 0.0 & 4 & 2.6 & 4 & 1.3 \\
\hline $\begin{array}{l}\text { Susu } \\
\text { formula }\end{array}$ & 37 & 24.0 & 20 & 13.0 & 57 & 18.5 \\
\hline Jumlah & 154 & 100.0 & $\begin{array}{r}15 \\
4 \\
\end{array}$ & 100.0 & 308 & 100.0 \\
\hline
\end{tabular}

Berdasarkan tabel 5.2 diatas dilakukan pengkatagorian sesuai dengan definisi operasional menjadi tiga katagori seperti terlihat pada tabel 5.3 berikut.

Tabel 3. Katagori Cara Pemberian ASI berdasarkan Kasus dan Kontrol di Kota Cimahi
Tabel 4. Hasil Analisis Bivariate Variabel Bebas Utama, Variabel Covariat Terhadap Kejadian Diare Pada Bayi 6-11 bulan di Puskesmas Kota Cimahi

\begin{tabular}{|c|c|c|c|c|c|c|c|}
\hline \multirow{2}{*}{ Variabel } & \multicolumn{2}{|c|}{ Kasus } & \multicolumn{2}{|c|}{ Kontrol } & \multirow[t]{2}{*}{ OR } & \multirow[t]{2}{*}{$95 \% \mathrm{CI}$} & \multirow[t]{2}{*}{$\begin{array}{l}P \\
\text { value }\end{array}$} \\
\hline & $\mathbf{n}$ & $\%$ & $\mathbf{n}$ & $\%$ & & & \\
\hline \multicolumn{8}{|c|}{ Cara pemberian ASI } \\
\hline Bukan ASI & 62 & 40.3 & 41 & 26.6 & 1.061 & \multirow{3}{*}{$\begin{array}{l}0.55- \\
2.04 \\
0.33- \\
0.90 \\
\text { (referens) }\end{array}$} & 0.858 \\
\hline ASI Perah & 21 & 13.6 & 27 & 17.5 & .546 & & 0.019 \\
\hline $\begin{array}{l}\text { ASI } \\
\text { Langsung }\end{array}$ & 71 & 46.1 & 86 & 55.8 & 1 & & \\
\hline \multicolumn{8}{|c|}{ Pendidikan Ibu } \\
\hline Rendah & 142 & 92.2 & 134 & 87.0 & 1.766 & \multirow{2}{*}{$\begin{array}{l}0.83- \\
2.17 \\
\text { (referens) }\end{array}$} & \multirow[t]{2}{*}{0.191} \\
\hline Tinggi & 12 & 7.8 & 20 & 13.0 & 1 & & \\
\hline \multicolumn{8}{|c|}{ Pekerjaan Ibu } \\
\hline Bekerja & 28 & 18.2 & 26 & 16.9 & 1.094 & \multirow{2}{*}{$\begin{array}{l}0.61- \\
1.97 \\
\text { (referens) }\end{array}$} & \multirow[t]{2}{*}{0.881} \\
\hline $\begin{array}{l}\text { Tidak } \\
\text { bekerja }\end{array}$ & 126 & 81.8 & 128 & 83.1 & 1 & & \\
\hline \multicolumn{8}{|c|}{ Status Sosial Ekonomi } \\
\hline Kurang & 44 & 28.6 & 42 & 27.3 & 1.067 & \multirow{2}{*}{$\begin{array}{l}0.65- \\
1.76 \\
\text { (referens) }\end{array}$} & \multirow[t]{2}{*}{0.899} \\
\hline Cukup & 110 & 71.4 & 112 & 72.7 & 1 & & \\
\hline \multicolumn{8}{|c|}{ Hygiene makanan minuman } \\
\hline Kurang & 76 & 49.4 & 45 & 29.2 & 2.360 & \multirow{2}{*}{$\begin{array}{l}1.48- \\
3.77 \\
\text { (referens) }\end{array}$} & \multirow[t]{2}{*}{0.000} \\
\hline Cukup & 78 & 50.6 & 109 & 70.8 & 1 & & \\
\hline \multicolumn{8}{|c|}{ Jenis kelamin } \\
\hline Pria & 71 & 46.1 & 77 & 50.0 & .855 & \multirow{2}{*}{$\begin{array}{l}0.55- \\
1.334 \\
\text { (referens) }\end{array}$} & \multirow[t]{2}{*}{.569} \\
\hline Wanita & 83 & 53.9 & 77 & 50.0 & 1 & & \\
\hline \multicolumn{8}{|l|}{ Usia Bayi } \\
\hline$\geq 9$ bulan & 91 & 59.1 & 94 & 61.0 & .922 & \multirow{2}{*}{$\begin{array}{l}0.58-1.46 \\
\text { (referens) }\end{array}$} & \multirow[t]{2}{*}{.816} \\
\hline$<9$ bulan & 63 & 40.9 & 60 & 39.0 & 1 & & \\
\hline \multicolumn{8}{|l|}{ MP ASI } \\
\hline Kurang & 30 & 19.5 & 50 & 32.5 & 0.503 & \multirow{2}{*}{$\begin{array}{l}0.29- \\
0.85 \\
\text { (referens) }\end{array}$} & \multirow[t]{2}{*}{0.014} \\
\hline Cukup & 124 & 80.5 & 104 & 67.5 & 1 & & \\
\hline Status Gizi & & & & & & & \\
\hline Kurang & 13 & 8.4 & 13 & 8.4 & $\begin{array}{l}1.00 \\
0\end{array}$ & $\begin{array}{l}0.45- \\
2.23\end{array}$ & 1.000 \\
\hline Baik & 141 & 91.6 & 141 & 91.6 & 1 & (referens) & \\
\hline
\end{tabular}

Pada penelitian ini analisis stratifikasi dilakukan untuk melihat besar asosiasi cara pemberian ASI terhadap kejadian diare berdasarkan strata variabel kovariat. Hasil analisis stratifikasi seperti terlihat pada tabel 5 
Tabel 5. Hasil Analisis Stratifikasi Hubungan Cara Pemberian ASI Terhadap Kejadian Diare Pada Bayi 6-11 bulan di Puskesmas Kota Cimahi

\begin{tabular}{|c|c|c|c|c|c|c|c|c|}
\hline \multirow{2}{*}{ Variabel } & \multicolumn{2}{|c|}{ Kasus } & \multicolumn{2}{|c|}{ Kontrol } & \multirow[t]{2}{*}{ OR } & \multicolumn{2}{|c|}{ 95\% CI } & $P$ value \\
\hline & $\mathbf{n}$ & $\%$ & $\mathbf{n}$ & $\%$ & & lower & upper & \\
\hline \multicolumn{9}{|l|}{$\begin{array}{l}\text { Pendidikan Ibu } \\
\text { Rendah }\end{array}$} \\
\hline Bukan ASI & 57 & 40.1 & 36 & 26.9 & .573 & .337 & .974 & .040 \\
\hline ASI Perah & 17 & 12.0 & 23 & 17.2 & 1.227 & .605 & 2.489 & .571 \\
\hline \multicolumn{9}{|l|}{ Tinggi } \\
\hline Bukan ASI & 5 & 41.7 & 5 & 25.0 & .273 & .046 & 1.616 & .152 \\
\hline ASI Perah & 4 & 33.3 & 4 & 20.0 & .273 & .041 & 1.795 & .177 \\
\hline ASI Langsung & 3 & 25.0 & 11 & 55.0 & & & & \\
\hline \multicolumn{9}{|l|}{ Pekerjaan Ibu } \\
\hline \multicolumn{9}{|l|}{ Bekerja } \\
\hline Bukan ASI & 16 & 57.1 & 12 & 46.2 & .375 & .059 & 2.397 & .300 \\
\hline ASI Perah & 10 & 35.7 & 10 & 38.5 & .500 & .074 & 3.378 & .477 \\
\hline ASI Langsung & 2 & 7.1 & 4 & 15.4 & & & & \\
\hline \multicolumn{9}{|l|}{ Tidak bekerja } \\
\hline Bukan ASI & 46 & 36.5 & 29 & 22.7 & .530 & .302 & .933 & .028 \\
\hline ASI Perah & 11 & 8.7 & 17 & 13.3 & 1.300 & .571 & 2.962 & .532 \\
\hline ASI Langsung & 69 & 54.8 & 82 & 64.1 & & & & \\
\hline \multicolumn{9}{|c|}{ Status Sosial Ekonomi } \\
\hline Kurang & 13 & 29.5 & 10 & 23.8 & .801 & .296 & 2.171 & .663 \\
\hline Bukan ASI & 6 & 13.6 & 8 & 19.0 & 1.389 & .419 & 4.600 & .591 \\
\hline ASI Perah & 25 & 56.8 & 24 & 57.1 & & & & \\
\hline ASI Langsung & 13 & 29.5 & 10 & 23.8 & .801 & .296 & 2.171 & .663 \\
\hline \multicolumn{9}{|l|}{ Cukup } \\
\hline Bukan ASI & 49 & 44.5 & 31 & 27.7 & .469 & .260 & .847 & .012 \\
\hline ASI Perah & 15 & 13.6 & 19 & 17.0 & .940 & .432 & 2.044 & .876 \\
\hline ASI Langsung & 46 & 41.8 & 62 & 55.4 & & & & \\
\hline \multicolumn{9}{|c|}{ Hygiene makanan minuman } \\
\hline \multicolumn{9}{|c|}{ Kurang } \\
\hline Bukan ASI & 37 & 48.7 & 14 & 31.1 & .473 & .209 & 1.070 & .072 \\
\hline ASI Perah & 9 & 11.8 & 7 & 15.6 & .972 & .316 & 2.992 & .961 \\
\hline ASI Langsung & 30 & 39.5 & 24 & 53.3 & & & & \\
\hline \multicolumn{9}{|l|}{ Cukup } \\
\hline Bukan ASI & 25 & 32.1 & 27 & 24.8 & .714 & .365 & 1.399 & .326 \\
\hline ASI Perah & 12 & 15.4 & 20 & 18.3 & 1.10 & .487 & 2.495 & .816 \\
\hline ASI Langsung & 41 & 52.6 & 62 & 56.9 & & & & \\
\hline
\end{tabular}




\begin{tabular}{|c|c|c|c|c|c|c|c|c|}
\hline \multirow{2}{*}{ Variabel } & \multicolumn{2}{|c|}{ Kasus } & \multicolumn{2}{|c|}{ Kontrol } & \multirow{2}{*}{ OR } & \multicolumn{2}{|c|}{$95 \%$ CI } & \multirow{2}{*}{$P$ value } \\
\hline & $\mathbf{n}$ & $\%$ & $\mathbf{n}$ & $\%$ & & lower & upper & \\
\hline \multicolumn{9}{|l|}{ Jenis kelamin } \\
\hline \multicolumn{9}{|l|}{ Pria } \\
\hline Bukan ASI & 25 & 35.2 & 22 & 28.6 & .834 & .401 & 1.734 & .626 \\
\hline ASI Perah & 10 & 14.1 & 17 & 22.1 & 1.61 & .652 & 3.979 & .302 \\
\hline ASI Langsung & 36 & 50.7 & 38 & 49.4 & & & & \\
\hline \multicolumn{9}{|l|}{ Wanita } \\
\hline Bukan ASI & 37 & 44.6 & 19 & 24.7 & .374 & .185 & .757 & .006 \\
\hline ASI Perah & 11 & 13.3 & 10 & 13.0 & .663 & .254 & 1.733 & .402 \\
\hline ASI Langsung & 35 & 42.2 & 48 & 62.3 & & & & \\
\hline \multicolumn{9}{|l|}{ Usia Bayi } \\
\hline \multicolumn{9}{|l|}{$\geq 9$ bulan } \\
\hline Bukan ASI & 36 & 39.6 & 25 & 26.6 & .524 & .275 & .999 & .050 \\
\hline ASI Perah & 12 & 13.2 & 12 & 12.8 & .754 & .309 & 1.842 & .536 \\
\hline ASI Langsung & 43 & 47.3 & 57 & 60.6 & & & & \\
\hline \multicolumn{9}{|l|}{$<9$ bulan } \\
\hline Bukan ASI & 26 & 41.3 & 16 & 26.7 & .594 & .264 & 1.337 & .208 \\
\hline ASI Perah & 9 & 14.3 & 15 & 25.0 & 1.61 & .606 & 4.271 & .339 \\
\hline ASI Langsung & 28 & 44.4 & 29 & 48.3 & & & & \\
\hline \multicolumn{9}{|l|}{ MP ASI } \\
\hline \multicolumn{9}{|l|}{ Kurang } \\
\hline Bukan ASI & 8 & 26.7 & 12 & 24.0 & .964 & .330 & 2.819 & .947 \\
\hline ASI Perah & 4 & 13.3 & 10 & 20.0 & 1.607 & .437 & 5.909 & .475 \\
\hline ASI Langsung & 18 & 60.0 & 28 & 56.0 & & & & \\
\hline \multicolumn{9}{|l|}{ Cukup } \\
\hline Bukan ASI & 54 & 43.5 & 29 & 27.9 & .491 & .273 & .881 & .017 \\
\hline ASI Perah & 17 & 13.7 & 17 & 16.3 & .914 & .424 & 1.971 & .818 \\
\hline ASI Langsung & 53 & 42.7 & 58 & 55.8 & & & & \\
\hline \multicolumn{9}{|l|}{ Status Gizi } \\
\hline \multicolumn{9}{|l|}{ Kurang } \\
\hline Bukan ASI & 3 & 23.1 & 3 & 23.1 & 1.500 & .223 & 10.077 & .677 \\
\hline ASI Perah & 1 & 7.7 & 4 & 30.8 & 6.000 & .532 & 67.649 & .147 \\
\hline ASI Langsung & 9 & 69.2 & 6 & 46.2 & & & & \\
\hline \multicolumn{9}{|l|}{ Baik } \\
\hline Bukan ASI & 59 & 41.8 & 38 & 27.0 & .499 & .295 & .844 & .010 \\
\hline ASI Perah & 20 & 14.2 & 23 & 16.3 & .891 & .449 & 1.768 & .742 \\
\hline ASI Langsung & 62 & 44.0 & 80 & 56.7 & & & & \\
\hline
\end{tabular}


Tabel 6. Kandidat Variabel yang akan

Disertakan dalam Model Multivariat

\begin{tabular}{lccl}
\hline \multicolumn{1}{c}{ Variabel } & OR & 95\% CI & P value \\
\hline Cara pemberian ASI (1) & 1.061 & $0.55-2.04$ & 0.858 \\
Cara pemberian ASI (2) & .546 & $0.33-0.90$ & $\mathbf{0 . 0 1 9}$ \\
$\begin{array}{l}\text { Pendidikan Ibu } \\
\text { Hygiene makanan }\end{array}$ & 1.766 & $0.83-2.17$ & 0.191 \\
$\begin{array}{l}\text { minuman } \\
\text { Makanan Pendamping }\end{array}$ & 2.360 & $1.48-3.77$ & $\mathbf{0 . 0 0 0}$ \\
ASI & 0.503 & $0.29-0.85$ & $\mathbf{0 . 0 1 4}$ \\
\hline
\end{tabular}

Tabel 7. Hasil Identifikasi Efek Modifikasi dengan Log Lihelihood

\begin{tabular}{|c|c|c|c|c|c|c|c|}
\hline \multirow{2}{*}{ Model } & \multirow{2}{*}{ OR } & \multicolumn{2}{|c|}{$95 \% \mathrm{CI}$} & \multirow[t]{2}{*}{ p value } & \multirow[t]{2}{*}{$-\mathbf{L L}$} & \multirow[t]{2}{*}{$\Delta \mathbf{L L}$} & \multirow[t]{2}{*}{ Ket } \\
\hline & & lower & upper & & & & \\
\hline Model Awal & & & & & 400.827 & & \\
\hline $\begin{array}{l}\text { Cara pemberian ASI } 1 \\
\text { (kASI1) }\end{array}$ & .635 & .375 & 1.073 & .090 & & & \\
\hline $\begin{array}{l}\text { Cara pemberian ASI } 2 \\
\text { (kASI2) }\end{array}$ & 1.011 & .516 & 1.982 & .975 & & & \\
\hline Pendidikan ibu (kdidik) & 1.842 & .839 & 4.046 & .128 & & & \\
\hline $\begin{array}{l}\text { Hygiene makanan } \\
\text { minuman (kHSM) }\end{array}$ & 2.264 & 1.395 & 3.673 & .001 & & & \\
\hline $\begin{array}{l}\text { Makanan Pendamping } \\
\text { ASI (mpasi) }\end{array}$ & .486 & .282 & .837 & .009 & & & \\
\hline $\begin{array}{l}\text { Model + Interaksi } \\
\text { (kASI*HSM) }\end{array}$ & & & & & 400.443 & 0.384 & $\begin{array}{l}\text { Tidak ada } \\
\text { interaksi }\end{array}$ \\
\hline $\begin{array}{l}\text { Cara pemberian ASI } 1 \\
\text { (kASI1) }\end{array}$ & .521 & .227 & 1.194 & .123 & & & \\
\hline $\begin{array}{l}\text { Cara pemberian ASI } 2 \\
\text { (kASI2) }\end{array}$ & .873 & .276 & 2.763 & .818 & & & \\
\hline Pendidikan ibu (kdidik) & 1.844 & .833 & 4.078 & .131 & & & \\
\hline $\begin{array}{l}\text { Hygiene makanan } \\
\text { minuman (kHSM) }\end{array}$ & 1.953 & .990 & 3.852 & .054 & & & \\
\hline $\begin{array}{l}\text { Makanan Pendamping } \\
\text { ASI (mpasi) }\end{array}$ & .490 & .284 & .845 & .010 & & & \\
\hline kASI(1) $*$ HSM & 1.391 & .476 & 4.065 & .546 & & & \\
\hline $\operatorname{kASI}(2) * \mathrm{HSM}$ & 1.252 & .303 & 5.176 & .757 & & & \\
\hline $\begin{array}{l}\text { Model + Interaksi ( } \\
\text { kASI*mpasi) }\end{array}$ & & & & & 399.521 & 1.306 & $\begin{array}{l}\text { Tidak ada } \\
\text { interaksi }\end{array}$ \\
\hline $\begin{array}{l}\text { Cara pemberian ASI } 1 \\
\text { (kASI1) }\end{array}$ & 1.050 & .351 & 3.142 & .930 & & & \\
\hline $\begin{array}{l}\text { Cara pemberian ASI } 2 \\
\text { (kASI2) }\end{array}$ & 1.540 & .406 & 5.846 & .526 & & & \\
\hline $\begin{array}{l}\text { Pendidikan ibu } \\
\text { (kdidik) }\end{array}$ & 1.892 & .857 & 4.175 & .114 & & & \\
\hline $\begin{array}{l}\text { Hygiene makanan } \\
\text { minuman (kHSM) }\end{array}$ & 2.245 & 1.382 & 3.646 & .001 & & & \\
\hline $\begin{array}{l}\text { Makanan Pendamping } \\
\text { ASI (mpasi) }\end{array}$ & .642 & .313 & 1.315 & .226 & & & \\
\hline $\operatorname{kASI}(1) *$ mpasi & .516 & .148 & 1.802 & .299 & & & \\
\hline $\operatorname{kASI}(2) *$ mpasi & .562 & .120 & 2.637 & .465 & & & \\
\hline
\end{tabular}




\begin{tabular}{|c|c|c|c|c|c|c|c|}
\hline \multirow{2}{*}{ Model } & \multirow{2}{*}{ OR } & \multicolumn{2}{|c|}{$95 \% \mathrm{CI}$} & \multirow[t]{2}{*}{ p value } & \multirow[t]{2}{*}{$-\mathbf{L L}$} & \multirow[t]{2}{*}{$\Delta \mathbf{L L}$} & \multirow[t]{2}{*}{ Ket } \\
\hline & & lower & upper & & & & \\
\hline $\begin{array}{l}\text { Model + Interaksi } \\
\text { ( kASI*kdidik) }\end{array}$ & & & & & 399.213 & 1.614 & $\begin{array}{l}\text { Tidak ada } \\
\text { interaksi }\end{array}$ \\
\hline $\begin{array}{l}\text { Cara pemberian ASI } 1 \\
\text { (kASI1) }\end{array}$ & .670 & .386 & 1.163 & .155 & & & \\
\hline $\begin{array}{l}\text { Cara pemberian ASI } 2 \\
\text { (kASI2) }\end{array}$ & 1.183 & .573 & 2.444 & .650 & & & \\
\hline $\begin{array}{l}\text { Pendidikan ibu } \\
\text { (kdidik) }\end{array}$ & 3.288 & .861 & 12.560 & .082 & & & \\
\hline $\begin{array}{l}\text { Hygiene makanan } \\
\text { minuman (kHSM) }\end{array}$ & 2.217 & 1.363 & 3.608 & .001 & & & \\
\hline $\begin{array}{l}\text { Makanan Pendamping } \\
\text { ASI (mpasi) }\end{array}$ & .487 & .283 & .839 & .010 & & & \\
\hline kASI(1) * kdidik & .484 & .073 & 3.200 & .451 & & & \\
\hline $\operatorname{kASI}(2) * \operatorname{kdidik}$ & .272 & .034 & 2.180 & .220 & & & \\
\hline
\end{tabular}

Indentifikasi confounding dilakukan setelah mengidentifikasi efek modifikasi, seperti tabel 8 .

Tabel 8. Hasil Identifikasi Confounding Model Multivariate

\begin{tabular}{|c|c|c|c|c|c|c|}
\hline \multirow{2}{*}{ Model Regresi Logistik } & \multirow{2}{*}{ OR } & \multicolumn{2}{|c|}{$95 \% \mathrm{CI}$} & \multirow[t]{2}{*}{$p$ value } & \multirow[t]{2}{*}{$\Delta \mathrm{OR}(\%)$} & \multirow[t]{2}{*}{ ket } \\
\hline & & lower & upper & & & \\
\hline $\begin{array}{l}\text { Cara pemberian ASI } 1 \\
\text { (kASI1) }\end{array}$ & $.635^{\mathrm{a}}$ & .375 & 1.073 & .090 & - & Model awal \\
\hline $\begin{array}{l}\text { Cara pemberian ASI } 2 \\
\text { (kASI2) }\end{array}$ & $1.011^{\mathrm{a}}$ & .516 & 1.982 & .975 & - & \\
\hline Pendidikan ibu (kdidik) & 1.842 & .839 & 4.046 & $.128 *$ & & \\
\hline $\begin{array}{l}\text { Hygiene makanan minuman } \\
\text { (kHSM) }\end{array}$ & 2.264 & 1.395 & 3.673 & .001 & & \\
\hline $\begin{array}{l}\text { Makanan Pendamping ASI } \\
\text { (mpasi) }\end{array}$ & .486 & .282 & .837 & .009 & & \\
\hline Cara pemberian ASI 1 (kASI1) & $641^{\mathrm{b}}$ & .380 & 1.081 & .095 & 0.94 & Model tanpa \\
\hline Cara pemberian ASI 2 (kASI2) & $1.057^{\mathrm{b}}$ & .541 & 2.065 & .871 & 4.35 & $\begin{array}{l}\text { variabel } \\
\text { pendidikan }\end{array}$ \\
\hline $\begin{array}{l}\text { Hygiene makanan minuman } \\
\text { (kHSM) }\end{array}$ & 2.292 & 1.415 & 3.712 & .001 & & \\
\hline $\begin{array}{l}\text { Makanan Pendamping ASI } \\
\text { (mpasi) }\end{array}$ & .506 & .295 & .868 & $.013 *$ & & \\
\hline Cara pemberian ASI 1 (kASI1) & $.603^{\mathrm{b}}$ & .360 & 1.011 & .055 & 5.31 & Model tanpa \\
\hline Cara pemberian ASI 2 (kASI2) & $1.055^{\mathrm{b}}$ & .544 & 2.046 & .875 & 4.17 & $\begin{array}{c}\text { variabel MP } \\
\text { ASI }\end{array}$ \\
\hline $\begin{array}{l}\text { Hygiene makanan minuman } \\
\text { (kHSM) }\end{array}$ & 2.218 & 1.379 & 3.567 & $.001 *$ & & \\
\hline Cara pemberian ASI 1 (kASI1) & $.546^{\mathrm{b}}$ & .330 & .904 & .019 & 16.30 & $\begin{array}{l}\text { Model tanpa } \\
\text { variabel }\end{array}$ \\
\hline Cara pemberian ASI 2 (kASI2) & $1.061^{\mathrm{b}}$ & .554 & 2.036 & .858 & 4.71 & $\begin{array}{l}\text { hygiene } \\
\text { makanan } \\
\text { minuman }\end{array}$ \\
\hline
\end{tabular}

${ }^{*}=$ kandidat variabel yang dieliminasi, ${ }^{\mathrm{a}}=\mathrm{OR}$ gold, ${ }^{\mathrm{b}}=\mathrm{OR}$ reduce

Variabel yang dimasukan ke dalam model akhir setelah melewati analisis stratifikasi dan confounding adalah cara pemberian ASI dan hygiene makanan minuman seperti terlihat pada tabel 9. berikut. 
Tabel 9. Model Akhir Regresi Logistik Hubungan Cara Pemberian ASI Terhadap Kejadian Diare Pada Bayi 6-11 bulan di Puskesmas Kota Cimahi

\begin{tabular}{|c|c|c|c|c|c|}
\hline \multirow{2}{*}{$\begin{array}{c}\text { Model Regresi } \\
\text { Logistik }\end{array}$} & \multirow{2}{*}{$\beta$} & \multirow{2}{*}{ OR } & \multicolumn{2}{|c|}{$95 \% \mathrm{CI}$} & \multirow{2}{*}{$\begin{array}{c}\mathbf{p} \\
\text { value }\end{array}$} \\
\hline & & & lower & upper & \\
\hline $\begin{array}{l}\text { Cara pemberian } \\
\text { ASI } 1 \text { (kASI1) }\end{array}$ & $\begin{array}{r}- \\
.50 \\
5\end{array}$ & .603 & .360 & 1.011 & .055 \\
\hline $\begin{array}{l}\text { Cara pemberian } \\
\text { ASI } 2(\mathrm{kASI} 2)\end{array}$ & $\begin{array}{r}.05 \\
3\end{array}$ & 1.055 & .544 & 2.046 & .875 \\
\hline $\begin{array}{l}\text { Hygiene } \\
\text { makanan } \\
\text { minuman } \\
(\mathrm{kHSM})\end{array}$ & $\begin{array}{r}.79 \\
7\end{array}$ & 2.218 & 1.379 & 3.567 & .001 \\
\hline Constant & $\begin{array}{r}- \\
.32 \\
7\end{array}$ & .721 & & & \\
\hline
\end{tabular}

\section{PEMBAHASAN}

Bias

Ancaman bias dengan desain kasus kontrol pada penelitian ini terutama yang berkaitan hasil pengukuran variabel cara pemberian ASI, hygiene makanan minuman dan makanan pendamping ASI yang ditanyakan 24 jam terakhir saat wawancara. Sementara outcome nya dimungkinkan sudah terjadi lebih dari 24 jam, sehingga terjadi potensial bias temporal ambiguity. Untuk menghindari terjadinya ketidaksebandingan kelompok kasus dan kontrol, maka kontrol diambil juga di puskesmas yang sama atau puskesmas terdekat dimana kasus diare diambil.

Bias informasi yang mungkin terjadi pada penelitian ini diantaranya adalah recall bias yang berkaitan dengan pertanyaan cara pemberian ASI, hygiene makanan minuman dan makanan pendamping ASI. Untuk mengurangi recall bias pada variabel tersebut penulis menggunakan 24 hour recall, sehingga kemungkinan untuk mengingat pada variabel tersebut masih dapat di recall dengan baik. Selain ketiga variabel tersebut di atas, kemungkinan recall bias dapat juga terjadi pada variabel status sosial ekonomi dimana responden harus menghitung jumlah pengeluaran per bulan.

Bias pengukuran juga dapat terjadi pada saat penentuan berat badan bayi untuk mendapatkan data status gizi dimana berat badan bayi diukur dengan menggunakan timbangan yang ada di puskesmas dan tidak dilakukan pengujian alat timbang oleh bidang metrologi, sehingga ketepatan berat badan bayi kurang akurat.

Bias misklasifikasi kemungkinan juga terjadi pada saat pemilihan kontrol. Kelompok kontrol kemungkinan juga mengalami outcome yang sama dengan kelompok kasus, namun tidak terdeteksi dalam sistem pelaporan puskesmas. Hal ini dikarenakan kelompok kontrol berobat ke klinik swasta atau rumah sakit. Untuk meminimalisir bias ini, maka kelompok kontrol diberikan pertanyaan tambahan untuk mengidentifikasi berkaitan dengan gejala diare pada bayi.

\section{Hubungan Faktor Risiko Penelitian}

Pada analisis bivariate diketahui bahwa pemberian ASI perah mempunyai efek proteksi/perlindungan 0.546 kali lebih kecil terhadap penyakit diare dibandingkan dengan bayi yang diberikan ASI langsung. Meskipun pada analisis bivariate ini ASI perah memberikan perlindungan dari pada ASI langsung namun perlu untuk ditinjau lagi penggunaan ASI perah pada bayi karena 
JURNAL SEHAT MASADA VOLUME XIII NOMOR 2 Juli 2019 ISSN : 1979-2344

menurut The Academy of Breastfeeding Medicine Protocol (ABM) (2010), usus bayi mungkin akan terpengaruh oleh bakteri lain yang berkembang dan diperkenalkan melalui kontaminasi di proses pengumpulan ASI. Pemberian ASI yang disimpan pada bayi mungkin memiliki konsekuensi yang berbeda pada kesehatan usus bayi dibandingkan dengan menyusui langsung.

Sementara pada analisis bivariat diketahui tidak terdapat hubungan yang bermakna antara cara pemberian bukan ASI/susu formula dengan kejadian diare $(\mathrm{p}=0.858)$. Hal ini bertolak belakang dengan penelitian Nakawesi et al (2010) menyebutkan bahwa bayi yang tidak diberi ASI setelah di adjusted berisiko 2,6 kali terjadinya diare rotavirus dibandingkan dengan bayi yang diberikan ASI.

Penelitian lainnya juga seperti Strand (2012) dan Girma (2011) bertolak belakang dengan hasil penelitian ini dimana pada penelitian Strand (2012) menyatakan bahwa balita yang tidak diberi ASI setelah di adjusted berisiko 9,3 kali terjadinya diare. sementara pada penelitian Girma (2011) OR tidak diberi ASI setelah di adjusted sebesar 13,2 kali.

Pada analisis multivariate, hasil penelitian ini menunjukan tidak ada hubungan yang bermakna antara cara pemberian ASI dengan kejadian diare pada bayi setelah dikontrol oleh variabel hygiene makanan minuman. Hal ini menunjukan bahwa cara pemberian ASI baik menggunakan susu formula, ASI perah maupun ASI langsung tidak memberikan risiko pada kejadian diare pada bayi 6-11 bulan. Meskipun beberapa referensi menyatakan bahwa penanganan tambahan yang terkait dengan memerah, penyimpanan, dan pemberian susu botol berikutnya dari ASI perah menghasilkan risiko tambahan untuk infeksi pada bayi (Geraghty, 2010 dalam Johns 2013). Selain itu untuk cara pemberian melalui ASI perah, ASI bersentuhan dengan berbagai obyek, mulai dari tangan manusia, alat pemerah, botol susu, yang semuanya mungkin tidak steril. Walaupun ASI sendiri steril, bersentuhan dengan benda-benda tadi menyebabkan pencemaran bakteri (Nenglita, 2011).

Penggunaan ASI perah di Kota Cimahi didapatkan sebesar $15.6 \%$ dimana ibu bayi yang memberikan ASI Perah berdomisili disekitar perbatasan dengan Kota Bandung. Hal ini dimungkinkan bahwa keterpaparan informasi mengenai ASI Perah lebih mudah didapatkan di Kota Bandung. Rendahnya penggunaan ASI perah ini juga dimungkinkan karena pada usia 6 bulan bayi sudah diperbolehkan mendapatkan Makanan Pendamping ASI sehingga sebagian besar ibu bayi beralih ke susu formula. Hal ini mungkin berbeda pada bayi usia kurang dari 6 bulan, dimana ibu bayi akan berusaha untuk mendapatkan "predikat" ASI eksklusif pada bayinya sehingga kemungkinan penggunaan ASI Perah pada usia kurang dari 6 bulan lebih tinggi.

Rendahnya penggunaan ASI perah di Kota Cimahi disebabkan karena sebagian besar ibu tidak bekerja baik pada kelompok kasus 
(81.8\%) maupun pada kelompok kontrol (83.1\%) sehingga sebagian besar ibu bayi memilih alternatif menyusui langsung. Selain itu pengambilan data di tingkat puskesmas memberikan peluang penggunaan ASI secara langsung cukup tinggi mengingat jam pelayanan puskesmas dibuka mulai pukul 8.00 hingga 12.00. Hal ini tidak memungkinkan bagi ibu bayi yang bekerja untuk membawa bayinya ke puskesmas. Selain itu bila dilihat dari variabel pendidikan, sebagian besar ibu bayi berpendidikan rendah (kasus $=92.2 \%$ dan kontrol $87.0 \%$ ) sehingga dimungkinkan keterpaparan informasi mengenai ASI perah sangat sulit. Kedua variabel tersebut (pekerjaan dan pendidikan) dimungkinkan berpengaruh terhadap hasil penggunaan ASI perah yang bersifat protektif terhadap kejadian diare.

Rendahnya penggunaan ASI perah di Kota Cimahi tidak menjadikan dasar bahwa cakupan ASI perah di Kota Cimahi hanya sebesar $15.6 \%$. Hal ini dikarenakan penelitian ini tidak melibatkan fasilitas pelayanan kesehatan lainnya seperti dokter praktek swasta, bidan praktek swasta, poli klinik kesehatan dan rumah sakit, yang membuka layanan kesehatan pada sore hingga malam hari. Fasilitas pelayanan kesehatan tersebut banyak digunakan oleh ibu yang berkerja sehingga kemungkinan penggunaan ASI perah pada ibu bekerja cukup tinggi.

Hasil penelitian ini belum memberikan cukup bukti bahwa penggunaan ASI perah dan bukan ASI (susu formula) berisiko untuk terjadinya diare.

\section{KESIMPULAN}

1. Pada kelompok kasus sebagian besar ibu bayi memberikan ASI langsung (46.1\%) dan bukan ASI/susu formula (40.3\%). Sementara yang memberikan ASI perah hanya sebesar 13.6\%. Pada kelompok kontrol ibu bayi yang memberikan ASI langsung kepada bayinya sebesar 55.8\%, yang memberikan bukan ASI/ susu formula sebesar $26.6 \%$ dan yang memberikan ASI perah hanya sebesar $17.5 \%$.

2. Terdapat hubungan yang bermakna antara cara pemberian ASI perah dengan kejadian diare pada bayi $(\mathrm{p}=0.019)$. Cara pemberian ASI perah mempunyai efek proteksi/perlindungan 0.546 kali lebih kecil terhadap penyakit diare dibandingkan dengan bayi yang diberikan ASI langsung. Sementara pada cara pemberian bukan ASI/susu formula diketahui tidak terdapat hubungan yang bermakna dengan kejadian diare $(\mathrm{p}=0.858)$

3. Tidak terdapat hubungan yang bermakna antara cara pemberian ASI dengan kejadian diare pada bayi setelah dikontrol variabel hygiene makanan minuman dengan $\mathrm{p}$ value sebesar 0.055 (95\%CI 0.360-1.011) dan 0.875 (95\%CI 0.360-1.011) 


\section{REFERENSI}

ABM Protocol (2010), ABM Clinical Protocol \#8: Human Milk Storage Information for Home use for Full-Term Infants (Original Protocol march 204; Revision \#1 march 2010), Breastfeeding Medicine, Volume 5, Number 3, 2010 CMary Ann Liebert, Inc

Annisakarnadi (2014), Cara Mudah Penyimpanan ASI Perah, www.duniasehat.html

Chin James (2009), Manual Pemberantasan Penyakit Menular, Editor Penterjemah Dr. I. Nyoman Kandun, MPHEdisi 17 Cetakan III tahun 2009, penerbit Infomedika.

Dinas Kesehatan kota Cimahi (2013), Profil Kesehatan Kota Cimahi Tahun 2013, Cimahi.

Gertsman, B.Burt (2003), Epidemiology kept Simple: An introduction to Traditional and Modern Epidemiology $\left(2^{\text {nd }} E d\right)$. New Jersey: Wiley-Liss

Girma and Berhane, (2011), Children who were vaccinated, breastfed, and from low parity mothers live longer: A community based case kontrol study in Jimma, Ethiopia, research article, BMC public health 2011, http://www.biomedcentral.com/14712334/13/567.

Johns HM et al (2013), Prevalence and outcomes of breast milk expressing in women with healthy term infants : a systematic review, Research article BMC Pregnancy and Childbirth, 13:212 http://www.biomedcentral.com/14712393/13/212.

Kemenkes RI (2011), Profil Kesehatan Indonesia 2010. http : //www.depkes.go.id/downloads/PROFIL _KESEHATAN_INDONESI

A_2010.pdf.

Nakawesi et al (2010), Prevalence And Faktors Associated With Rotavirus Infection Among Children Admitted With Acute Diarrhea In Uganda, research article, BMC public health 2010, http://www.biomedcentral.com/.

Nenglita (2011), Manajemen ASI Perah, www.mommiesdaily.com diunduh 11 febuari 2015
Strand et al, (2012), Risk faktor for ectenderd duration of acute diarrhea in young children, research article, Volume 7 2012, www.plosone.org 